$6(1), 2021,181-190$

\title{
JEKK
}

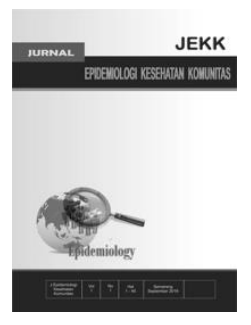

\section{Analisis Faktor Predisposing Terhadap Pemanfaatan Posyandu Balita Di Wilayah Kerja Puskesmas Tegal Binangun Kota Palembang}

\author{
Citrasari $^{*}$, Misnaniarti** $^{*}$, M. Zulkarnain ${ }^{* * *}$ \\ "Magister Ilmu Kesehatan Masyarakat, Fakultas Kesehatan Masyarakat, Universitas Sriwijaya, Palembang, \\ ***Fakultas Kesehatan Masyarakat, Universitas Sriwijaya, Palembang, ${ }^{* * *}$ Fakultas Kedokteran, Universitas \\ Sriwijaya, Palembang
}

\begin{abstract}
Background: The proportion of Posyandu utilization by infants decreases with age of the child. Tegal Binangun Puskesmas has the lowest coverage of posyandu visits, amounting to $66.30 \%$ of 41 puskesmas in Palembang..

Methods: An analytical research was conducted with cross sectional design in December 2019 February 2020. The research sample was mothers of toddlers 12 - 59 months in the working area of the Tegal Binangun Public Health Center, Palembang. 189 samples were selected by proportional random sampling. Data is taken from questionnaires and direct observation. Data were analyzed using chi-square and logistic regression.

Result: 153 respondents (81\%) with low use of posyandu. Statistical tests showed that age <30 years $(\mathrm{p}=001$. $\mathrm{PR}=3,464)$, number of children under five $(\mathrm{p}=0.041, \mathrm{PR}=3.509)$, under five age $(\mathrm{p}=0.029, \mathrm{PR}=2.806)$, mother employment status $(\mathrm{p}=0.030, \mathrm{PR}=4.675)$, mother's last education $(\mathrm{p}=0.033, \mathrm{PR}=2,421)$, mother's knowledge level $(\mathrm{p}=0,000, \mathrm{PR}=9,100)$, and mother's attitude variable $(\mathrm{p}=0.005, \mathrm{PR}=3,077$ ) related to the use of Posyandu in Tegal Binangun Health Center area. The knowledge level is the most dominant variable influencing the use of posyandu by toddlers aged 12-59 months. The researcher suggests that increasing the participation of all sectors in optimizing the implementation of posyandu.

Conclusion: There is a relationship between maternal age, number of toddlers, toddler age, maternal employment status, last education, mother's level of knowledge and mother's attitude towards the use of posyandu
\end{abstract}

Keywords: Use of posyandu ; toddlers ; factors.

*Penulis korespondensi, citra22.dinkes@gmail.com 


\section{Pendahuluan}

Kesehatan adalah hak azasi manusia dan sekaligus sebagai investasi, sehingga perlu diupayakan, diperjuangkan dan ditingkatkan oleh setiap individu dan oleh seluruh komponen bangsa, agar masyarakat dapat menikmati hidup sehat dan pada akhirnya dapat mewujudkan derajat kesehatan masyarakat yang optimal. Hal ini perlu dilakukan karena kesehatan bukanlah tanggung jawab pemerintah saja, namun juga merupakan tanggung jawab bersama pemerintah dan masyarakat, termasuk swasta. Selain itu juga dijelaskan bahwa adanya kebijakan tentang upaya pemeliharaan kesehatan bayi dan anak harus ditujukan untuk mempersiapkan generasi akan datang yang sehat, cerdas dan berkualitas serta untuk menurunkan angka kematian bayi dan anak. ${ }^{1}$

Sejalan dengan perkembangan paradigma pembangunan kesehatan, telah ditetapkan arah kebijakan pembangunan kesehatan yang tertuang dalam Rencana Pembangunan Jangka Menengah Nasional (RPJMN) 2020-2024 Bidang Kesehatan, yaitu memberikan fokus pada upaya meningkatkan akses dan kualitas pelayanan kesehatan menuju cakupan kesehatan semesta dengan penekanan pada penguatan pelayanan kesehatan dasar (primary health care) dan peningkatan upaya promotif dan preventif didukung oleh inovasi dan pemanfaatan teknologi. Adapun salah satu strategi penguatan RPJMN 2020 - 2024 yang perlu dilakukan adalah upaya revitalisasi posyandu dan UKBM sebagai bagian dari upaya penguatan Gerakan Masyarakat Hidup Sehat (Germas). Posyandu menjadi ujung tombak pencegahan stunting dengan melakukan pemantauan tumbuh kembang bayi dan balita di Indonesia. Presiden Joko Widodo berkali-kali dalam paparannya dalam rapat lintas kementerian mengatakan bahwa posyandu adalah garda terdepan pencegahan stunting. ${ }^{2}$

Indonesia merupakan negara kelima terbesar dengan anak stunted setelah India, Nigeria, Pakistan dan China. ${ }^{3}$ Hasil Riskesdas Tahun 2013 menunjukkan bahwa prevalensi anak balita Indonesia yang risiko stunting relatif tinggi yaitu sebesar $37,2 \%$ dan mengalami sedikit perbaikan menjadi $30,8 \%$ berdasarkan hasil Riskesdas 2018. Selain itu diketahui bahwa hasil SUPAS 2015, angka kematian ibu di Indonesia sebesar 305 / 100.000 kelahiran hidup dari target tahun 2024 sebesar 232 per 100.000 kelahiran hidup, angka kematian neonatal berdasarkan SDKI 2017 sebesar 15 per 1.000 kelahiran hidup dari target tahun 2024 sebesar 10 per 1.000 kelahiran hidup, angka kematian bayi sebesar 24 per 1.000 kelahiran hidup dari target tahun 2024 sebesar 16 per 1.000 kelahiran hidup serta angka kematian balita sebesar 32 per 1.000 kelahiran hidup dari target tahun 2024 sebesar 24 per 1.000 kelahiran hidup (BPS, 2016). Selain itu, diketahui juga bahwa cakupan imunisasi di Indonesia masih jauh dibawah target yang ditetapkan oleh UNICEF dan WHO sebesar $80 \%$ terutama pada kelompok umur 12 -23 bulan. $^{4}$

Iswarawanti $(2010)^{5}$ menyatakan bahwa status gizi menjadi sangat penting mengingat masa pertumbuhan anak terutama pada 2 tahun pertama kehidupan merupakan periode kritis bagi tumbuh kembang seorang anak. Kurang gizi atau gizi buruk pada anak merupakan masalah kesehatan masyarakat utama di negara berkembang termasuk Indonesia. Walaupun dalam beberapa dekade ini Indonesia mengalami penurunan masalah kekurangan gizi, namun kekurangan gizi akut dan kronis masih cukup tinggi. Data nasional menunjukkan bahwa ada $36,8 \%$ anak umur bawah lima tahun (balita) yang mengalami stunting (pendek dan sangat pendek, diukur dengan tinggi badan menurut umur). Indikator ini menunjukkan terjadinya kekurangan gizi dalam jangka waktu yang panjang atau kronis dikarenakan tingginya angka kesakitan atau rendahnya asupan makanan.

Perbaikan dan peningkatan gizi merupakan prasyarat utama dalam upaya meningkatkan kesehatan ibu hamil, penurunan angka kematian bayi dan balita, jaminan pertumbuhan fisik, perkembangan sosial dan mental anak-anak, prestasi kerja serta prestasi akademik. Oleh karena itu, status gizi masyarakat menjadi salah satu parameter yang penting dari kualitas sumber daya manusia. ${ }^{6}$

Ada upaya yang bisa dilakukan untuk mengurangi angka kesakitan dan kematian anak balita yaitu dengan melakukan 
pemeliharaan kesehatannya. Pemeliharaan kesehatan anak balita dititik beratkan kepada upaya pencegahan dan peningkatan kesehatan serta pengobatan dan rehabilitasi yang dapat dilakukan di puskesmas, puskesmas pembantu, poskesdes dan terutama di posyandu, karena posyandu merupakan tempat yang paling cocok untuk memberikan pelayanan kesehatan pada balita secara menyeluruh dan terpadu, dan kader menjadi sangat penting dalam mendorong masyarakat untuk senantiasa mengedepankan upaya pemeliharaan kesehatan. $^{7}$

Posyandu adalah salah satu bentuk upaya kesehatan berbasis masyarakat yang sudah menjadi milik masyarakat serta menyatu dalam kehidupan dan budaya masyarakat. Meskipun dalam satu dasa warsa terakhir ini terjadi perubahan kepemerintahan di Indonesia, tetapi posyandu masih tetap ada di tengah-tengah masyarakat kita. Keberadaan posyandu sangat diperlukan dalam mendekatkan upaya promotif dan preventif kepada masyarakat, utamanya terkait dengan upaya peningkatan status gizi masyarakat serta upaya kesehatan ibu dan anak. ${ }^{8}$ Posyandu juga merupakan salah satu Lembaga Kemasyarakatan Desa (LKD) yang melaksanakan pemberdayaan masyarakat desa termasuk kelurahan, ikut serta daam perencanaan dan pelaksanaan pembangunan desa/kelurahan serta meningkatkan pelayanan masyarakat desa/kelurahan. ${ }^{9}$

Pemanfaatan posyandu menjadi salah satu determinan terjadinya stunting pada balita. Keaktifan balita ke posyandu akan sangat besar pengaruhnya terhadap terpantaunya status gizi balita. Memantau pertumbuhan balita di posyandu merupakan upaya untuk mendeteksi dini terjadinya gangguan pertumbuhan sehingga dapat dilakukan pencegahan terjadinya balita stunting. ${ }^{10}$ Kunjungan posyandu kurang dari dua kali dalam enam bulan terakhir dapat meningkatkan risiko terjadinya stunting 2,57 kali lebih besar. ${ }^{11}$

Menurut Susenas 2011, hanya 40\% balita dilaporkan dibawa ke Posyandu dalam 1 bulan terakhir dan sekitar $28 \%$ balita tidak pernah dibawa mengunjungi ke posyandu. Jika ditinjau dari kelompok umurnya, yang terbanyak memanfaatkan Posyandu adalah bayi 0-11 bulan. Selanjutnya proporsi tersebut menurun seiring dengan meningkatnya umur anak. Di perkotaan lebih banyak yang tidak memanfaatkan posyandu dibandingkan di perdesaan $(30,6 \%$ untuk di pedesaan dan $25,7 \%$ untuk di perkotaan). Rendahnya pemanfaatan posyandu oleh ibu dipengaruhi oleh tingkat tingkat pengetahuan yang masih rendah tentang manfaat posyandu, oleh karenanya ibu tidak termotivasi untuk membawa bayi dan balitanya ke posyandu. ${ }^{10}$ Selain itu, data mengenai pemantauan pertumbuhan balita yang dilakukan setiap bulan menunjukkan bahwa persentase balita umur 6-59 bulan yang tidak pernah ditimbang dalam enam bulan terakhir cenderung meningkat dari 25,5\% (2007), 23,8\% (2010) menjadi $34,3 \% .{ }^{12}$ Secara kuantitas jumlah posyandu yang ada di provinsi Sumatera Selatan tahun 2018 sebanyak 6.630 posyandu. Dari jumlah tersebut, diketahui 291 posyandu $(4,39 \%)$ masih berstrata pratama, 2.295 posyandu $(34,62 \%)$ strata madya, 3.552 posyandu $(53,57 \%)$ strata purnama dan 492 posyandu $(7,42 \%)$ berstrata mandiri. Dari data tersebut, maka dapat disimpulkan bahwa di provinsi Sumatera Selatan terdapat sebanyak 2.586 posyandu yang tidak aktif (strata pratama dan madya) serta sebanyak 4.044 posyandu yang aktif (strata purnama dan mandiri). Selanjutnya diketahui bahwa Kota Palembang menjadi kabupaten/kota yang memiliki jumlah posyandu terbanyak di provinsi Sumatera Selatan yaitu sebanyak 910 posyandu dengan strata perkembangan posyandu aktif (purnama dan mandiri) baru sebesar $67,6 \% .^{13}$

Kota Palembang membawahi 41 (empat puluh satu) puskesmas dan Puskesmas Tegal Binangun memiliki cakupan kunjungan ke posyandu (D/S) terendah, yaitu sebesar 66,30\%. Ditinjau dari segi topografi, wilayah kerja Puskesmas Tegal Binangun terdiri dari dataran rendah berupa persawahan dengan wilayah kerja $320.000 \mathrm{KM}^{2}$, jumlah penduduk 30.040 jiwa yang tersebar di 2 (dua) kelurahan yaitu kelurahan Talang Putri dan Kelurahan Plaju darat. Kelurahan Talang Putri mempunyai 8 rukun warga dan 32 rukun 
tetangga, sedangkan kelurahan Plaju darat mempunyai 10 rukun warga dan 34 rukun tetangga. ${ }^{14}$

Rendahnya pemanfaatan posyandu oleh masyarakat dipengaruhi oleh perilaku orang tua balita dalam memanfaatkan posyandu. Berdasarkan teori Lawrence Green dijelaskan bahwa perilaku kesehatan seseorang dipengaruhi oleh tiga faktor, yaitu faktor predisposing (sikap masyarakat terhadap kesehatan, pengetahuan, tradisi dan kepercayaan masyarakat terhadap hal-hal terkait kesehatan, umur, jenis kelamin, dan sebagainya), faktor enabling atau pemungkin (jarak ke fasilitas kesehatan, ketersediaan sarana prasarana atau fasilitas kesehatan bagi masyarakat), serta faktor reinforcing atau penguat (dukungan tokoh masyarakat, tokoh agama, keluarga, dan sebagainya). ${ }^{15}$

Beberapa penelitian terdahulu juga telah membuktikan bahwa ada banyak faktor yang mempengaruhi masyarakat memilih memanfaatkan posyandu untuk pemantauan tumbuh kembang anaknya. Salah satu penelitian menyampaikan bahwa tingkat tingkat pengetahuan, sikap ibu dan peran kader merupakan faktor-faktor yang mempengaruhi keaktifan kunjungan ibu balita ke posyandu. ${ }^{16}$

\section{Metode}

Penelitian ini merupakan studi analitik dengan desain cross sectional yang dilaksanakan pada bulan Desember 2019 Februari 2020. Populasi penelitian adalah adalah balita umur 12-59 bulan yang ada di wilayah kerja Puskesmas Tegal Binangun Kota Palembang. Responden pada penelitian ini adalah ibu yang mempunyai balita umur 12-59 bulan di wilayah kerja Puskesmas Tegal Binangun Kota Palembang. Besarnya sampel untuk penelitian ini ditentukan dengan menggunakan rumus besar sampel desain cross sectional uji hipotesis dua proporsi. ${ }^{17}$ Terdapat 189 sampel yang memenuhi kriteria inklusi dan ekslusi. Kriteria inklusi adalah ibu yang mempunyai balita umur 12-59 bulan, berdomisili pada masing-masing kelurahan di wilayah kerja puskesmas Tegal Binangun minimal 1 tahun dan terdaftar dalam buku register posyandu. Pengambilan sampel dengan cara proporsional random sampling. Instrumen pengumpulan data adalah makalah pengumpulan data yang berisi variabel penelitian. Data diambil dari kuesioner tentang faktor predisposing, responden serta observasi langsung buku register posyandu dan buku KIA serta data dianalisis menggunakan chi chi square dan regresi logistik.

\section{Hasil}

Data pemanfaatan posyandu oleh ibu yang mempunyai balita umur 12-59 bulan di wilayah kerja puskesmas Tegal Binangun Kota Palembang dikategorikan menjadi dua, yaitu tinggi apabila datang ke posyandu $\geq 8$ kali dan rendah apabila $<8$ kali dalam setahun terakhir ${ }^{8}$. Hasil penelitian menunjukkan bahwa terdapat 153 responden $(81 \%)$ dengan pemanfaatan posyandu rendah dan ada 36 responden (19\%) dengan pemanfaatan posyandu tinggi yang dapat dilihat pada Tabel 1.

Tabel 1. Distribusi pemanfaatan posyandu

\begin{tabular}{lcc}
\hline Pemanfaatan & $\mathbf{n}$ & $\mathbf{\%}$ \\
\hline Rendah & 153 & 81 \\
Tinggi & 36 & 19 \\
\hline Total & $\mathbf{1 8 9}$ & $\mathbf{1 0 0}$ \\
\hline
\end{tabular}


Tabel 2. Hasil analisis bivariat variabel independen

\begin{tabular}{|c|c|c|c|c|c|c|}
\hline \multirow{3}{*}{ Variabel Independen } & \multicolumn{4}{|c|}{ Pemanfaatan Posyandu } & \multirow[t]{3}{*}{$\begin{array}{c}P \\
\text { value }\end{array}$} & \multirow[t]{3}{*}{$\begin{array}{c}\text { PR } \\
(95 \% \mathrm{CI})\end{array}$} \\
\hline & \multicolumn{2}{|c|}{ Rendah } & \multicolumn{2}{|c|}{ Tinggi } & & \\
\hline & $\mathrm{n}$ & $\%$ & $\mathrm{n}$ & $\%$ & & \\
\hline \multicolumn{7}{|l|}{ Umur Ibu } \\
\hline$<30$ tahun & 97 & 89 & 12 & 11 & 0,001 & 3,464 \\
\hline$\geq 30$ tahun & 56 & 70 & 24 & 30 & & $(1,609-7,460)$ \\
\hline \multicolumn{7}{|l|}{ Jumlah balita } \\
\hline 2 orang / lebih & 37 & 92,5 & 3 & 7,5 & 0,041 & 3,509 \\
\hline 1 orang & 116 & 77,9 & 33 & 22,1 & & $(1,017-12,106)$ \\
\hline \multicolumn{7}{|l|}{ Umur balita } \\
\hline $36-59$ bulan & 55 & 90,2 & 6 & 9,8 & 0,029 & 2,806 \\
\hline $12-35$ bulan & 98 & 76,6 & 30 & 23,4 & & $(1,100-7,160)$ \\
\hline \multicolumn{7}{|l|}{ Status pekerjaan } \\
\hline Bekerja & 33 & 94,3 & 2 & 5,7 & 0,030 & 4,675 \\
\hline Tidak bekerja & 120 & 77,9 & 34 & 22,1 & & $(1,067-20,480)$ \\
\hline \multicolumn{7}{|l|}{ Pendidikan terakhir } \\
\hline Tinggi & 115 & 85,2 & 20 & 14,8 & 0,033 & 2,421 \\
\hline Rendah & 38 & 70,4 & 16 & 29,6 & & $(1,140-5,140)$ \\
\hline \multicolumn{7}{|l|}{ Tingkat Pengetahuan } \\
\hline Rendah & 91 & 94,8 & 5 & 5,2 & 0,000 & 9,100 \\
\hline Tinggi & 62 & 66,7 & 31 & 33,3 & & $(3,354-24,692)$ \\
\hline \multicolumn{7}{|l|}{ Sikap ibu } \\
\hline Negatif & 88 & 88,9 & 11 & 11,1 & 0,005 & 3,077 \\
\hline Positif & 65 & 72,2 & 25 & 27,8 & & $(1,413-6,700)$ \\
\hline
\end{tabular}

Berdasarkan Tabel 2 analisis bivariat dengan uji chi square didapatkan 7 variabel yang bermakna secara statistik berhubungan dengan Pemanfaatan Posyandu di Wilayah Kerja Puskesmas Tegal Binangun Kota Palembang yaitu umur ibu $p=0,001$, jumlah balita $p=0,041$, umur balita $\mathrm{p}=0,029$, status pekerjaan $\mathrm{p}=0,030$, pendidikan terakhir $\mathrm{p}=0,030$, tingkat pengetahuan $\mathrm{p}=0,000$ dan sikap ibu $\mathrm{p}=0,005$. Dari nilai $\mathrm{p}$ pada analisis bivariat semua variabel masuk sebagai variabel kandidat pada analisis multivariat $(\mathrm{p}<0,25)$

Tabel 3. Hasil analisis multivariat

\begin{tabular}{|c|c|c|c|c|c|c|}
\hline \multicolumn{2}{|r|}{ Variabel } & \multirow{2}{*}{$\begin{array}{c}\text { B } \\
0,930\end{array}$} & \multirow{2}{*}{$\frac{\text { SE }}{0,468}$} & \multirow{2}{*}{$\begin{array}{r}\text { P value } \\
0,047\end{array}$} & \multirow{2}{*}{$\frac{\mathbf{P R}}{2,535}$} & \multirow{2}{*}{$\begin{array}{c}\text { PR } \\
(\mathbf{9 5 \%} \mathbf{C I})\end{array}$} \\
\hline Step 1 & Umur ibu (1) & & & & & \\
\hline & Jumlah balita (1) & $-1,443$ & 0,708 & 0,042 & 0,236 & $0,059-0,946$ \\
\hline & Umur balita (1) & 1,196 & 0,567 & 0,035 & 3,306 & $1,088-10,048$ \\
\hline & Status Pekerjaan (1) & 0,593 & 0,844 & 0,482 & 1,810 & $0,346-9,460$ \\
\hline & Pendidikan terakhir (1) & 1,073 & 0,467 & 0,022 & 2,923 & $1,170-7,303$ \\
\hline & Tingkat pengetahuan (1) & 1,658 & 0,567 & 0,003 & 5,246 & $1,726-15,950$ \\
\hline & Sikap ibu (1) & 1,206 & 0,471 & 0,010 & 3,349 & $1,327-8,397$ \\
\hline & Konstanta & 0,079 & 0,773 & 0,919 & 1,082 & \\
\hline
\end{tabular}




\begin{tabular}{llrrrrr}
\hline \multicolumn{1}{c}{ Variabel } & B & SE & P value & PR & \multicolumn{1}{c}{$\begin{array}{c}\text { PR } \\
\text { (95\% CI) }\end{array}$} \\
\hline Step 2 & Umur ibu (1) & 0,960 & 0,466 & 0,039 & 2,611 & $1,048-6,502$ \\
& Jumlah balita (1) & $-1,456$ & 0,705 & 0,039 & 0,233 & $0,059-0,927$ \\
& Umur balita (1) & 1,231 & 0,564 & 0,029 & 3.425 & $1,134-10,350$ \\
& Pendidikan terakhir (1) & 1,077 & 0,467 & 0,021 & 2,936 & $1,177-7,326$ \\
& Tingkat Pengetahuan (1) & 1,766 & 0,550 & 0,001 & 5,849 & $1,989-17,199$ \\
& Sikap ibu (1) & 1,193 & 0,467 & 0,011 & 3,299 & $1,321-8,236$ \\
Konstanta & 0,105 & 0,774 & 0,892 & 1,110 & \\
\hline
\end{tabular}

Hasil analisis pada Tabel 3 merupakan pemodelan analisis multivariat dimana terdapat 6 variabel yang masuk hingga ke pemodelan akhir. Melalui analisis multivariat diketahui bahwa variabel yang berhubungan dengan pemanfaatan posyandu di wilayah kerja Puskesmas Tegal Binangun Kota Palembang adalah umur ibu $(\mathrm{p}=0,039 ; 95 \% \mathrm{CI}=1,048$ $6,50)$; jumlah balita $(\mathrm{p}=0,039 ; 95 \% \mathrm{CI}=0,059$ $0,927)$; umur balita ( $\mathrm{p}=0,029 ; 95 \% \mathrm{CI}=1,134-$ 10,350); pendidikan terakhir $(\mathrm{p}=0,021$, $\mathrm{CI}=1,177-7,326)$; tingkat pengetahuan ( $\mathrm{p}=0,001,95 \% \mathrm{CI}=1,989-17,199)$; dan sikap ibu ( $\mathrm{p}=0,011,95 \% \mathrm{CI}=1,321-8,236)$.

\section{Pembahasan}

Pos Pelayanan Terpadu (Posyandu) merupakan suatu bentuk keterpaduan pelayanan kesehatan dan keluarga berencana yang dilaksanakan di tingkat desa/kelurahan dalam wilayah kerja masing-masing puskesmas. Posyandu berperan sebagai wadah yang dibentuk secara swadaya masyarakat sebagai filter awal dalam perbaikan dan peningkatan derajat kesehatan masyarakat utamanya terkait kesehatan ibu dan anak. Biasanya posyandu dilakukan di balai desa/kelurahan dengan menggunakan mekanisme lima meja dengan urutan dimulai dari pendaftaran, penimbangan dan pengukuran, pencatatan, penyuluhan/ pemberian informasi kesehatan serta pelayanan kesehatan. Diharapkan dengan terselenggaranya kegiatan ini secara baik maka posyandu dapat menjadi sarana surveillance yang baik utamanya dalam mencegah terjadinya permasalahan gizi, baik gizi kurang, gizi buruk, gizi lebih maupun stunting. ${ }^{8}$

Perilaku pemanfaatan posyandu adalah salah satu dari bentuk perilaku kesehatan khususnya yang berhubungan dengan sistim pelayanan kesehatan. Perilaku ini menyangkut respon seseorang terhadap fasilitas pelayanan kesehatan, cara pelayanan, petugas kesehatan dan obat-obatan yang terwujud dalam pengetahuan, persepsi, sikap dan penggunaan fasilitas, petugas dan obat-obatan. ${ }^{18}$

Kehadiran ibu di posyandu secara rutin dengan membawa balitanya sangat mendukung tercapainya salah satu tujuan posyandu yaitu meningkatkan kesehatan ibu dan balita. Tetapi kenyataannya, tidak semudah dan sesederhana seperti yang diperkirakan. Partisipasi masyarakat merupakan hal yang kompleks dan sering sulit diperhitungkan karena terlalu banyak faktor yang mempengaruhinya. ${ }^{19}$

Dari hasil penelitian diketahui bahwa hanya 36 (19\%) ibu yang mempunyai balita umur $12-59$ bulan tinggi dalam pemanfaatan posyandu ( $8-12$ kali dalam setahun terakhir), masih dibawah target nasional yaitu minimal $85 \%$. Hasil penelitian berbeda jauh dengan data kunjungan D/S yang dilaporkan pada tahun 2019 yaitu sebesar 80,4\%. Kondisi ini memberikan gambaran bahwa permasalahan terkait pemantauan tumbuh kembang anak adalah fenomena gunung es, permasalahan terlihat atau terlaporkan adalah sebagian kecil dari kondisi yang sebenarnya ada/terjadi. Hal tersebut dapat menyebabkan tidak terpantaunya tumbuh kembang anak balita yang akan berakibat tidak terdeteksinya masalah-masalah kesehatan balita secara dini termasuk masalah gangguan gizi. Dari pencatatan register posyandu terlihat bahwa angka kunjungan ke posyandu hanya mengalami peningkatan yang cukup signifikan pada bulan pemberian vitamin A (Februari - Agustus), sejalan dengan opini kader dan penanggung jawab posyandu di puskesmas yang menyampaikan bahwa bulan 
vitamin A menjadi salah satu pendongkrak angka kunjungan ke posyandu.

Hasil penelitian ini sejalan dengan gambaran situasi pemanfaatan posyandu di Indonesia bahwa pemanfaatan posyandu mengalami penurunan seiring dengan pertambahan umur balita, dimana pemanfaatan posyandu tertinggi pada kelompok umur balita $0-11$ bulan yang diketahui menjadi kelompok umur sasaran imunisasi wajib. ${ }^{20}$ Studi penelitian juga membuktikan bahwa ibu hanya rutin membawa balitanya ke posyandu setiap bulannya pada saat umur anak di bawah satu tahun untuk mendapatkan pelayanan imunisasi lengkap. Setelah anak berumur lebih dari satu tahun, ibu jarang membawa anaknya ke posyandu karena ibu belum menganggap penting kegiatan penimbangan dan pemantauan tumbuh kembang balita secara rutin dalam upaya pemeliharaan kesehatan balitanya. ${ }^{21}$

Berdasarkan hasil wawancara dan observasi di lapangan, responden menyatakan bahwa mereka rutin membawa balita ke posyandu setiap bulan pada saat umur anak dibawah satu tahun saja agar anaknya mendapatkan imunisasi wajib secara lengkap tetapi setelah satu tahun mereka mulai tidak rutin setiap bulan karena merasa anaknya sehat dan sudah cukup dengan imunisasi wajib selama 1 tahun saja. Anak balita yang sudah mulai belajar berjalan juga membuat beberapa orang tua mengatakan kewalahan menjaga anaknya ketika di posyandu yang biasanya harus antri walaupun tidak terlalu lama, ditambah tempat posyandu yang sempit dan panas yang sering kali membuat anak tidak betah dan menangis.

Kurangnya pemahaman dan pengetahuan akan manfaat posyandu dapat dipengaruhi oleh orang lain, keluarga, maupun dari diri sendiri yang disebabkan karena ketidaknyamanan pelayanan posyandu yang dilakukan oleh petugas kesehatan maupun kader. Pengalaman pribadi lainnya seperti ibu merasa bahwa balitanya sehat sehingga tidak perlu melakukan deteksi dini pemantauan tumbuh kembang di posyandu setiap bulannya juga masih dijumpai di lapangan. Tersedianya pilihan tempat imunisasi yang lebih fleksibel waktunya juga menjadi salah satu alasan yang mendorong ibu merasa tidak harus ke posyandu, walaupun dengan konsekuensi harus mengeluarkan biaya, seperti praktek bidan swasta, klinik bersalin, dan tempat pemeriksaan lainnya.

Rendahnya pemanfaatan posyandu dapat memperlihatkan bahwa perilaku masyarakat dalam bidang kesehatan yang diwujudkan sebagai perilaku preventif masih rendah dan belum dianggap sebagai hal yang perlu diprioritaskan dan penting untuk dilakukan. Hal ini bisa disebabkan karena semua komponen pendukung untuk terbentuknya perilaku yang baik belum dimiliki sepenuhnya oleh ibu balita. Selain itu, pemanfaatan posyandu yang diwujudkan dengan partisipasi dan kehadiran ibu yang memiliki balita secara rutin setiap bulan ke posyandu merupakan wujud perilaku ibu sebagai bagian dari agent of change, mendukung pertumbuhan dan perkembangan anak sesuai dengan potensi masing-masing. Seperti sebuah penelitian menyampaikan bahwa posyandu memiliki pengaruh yang cukup besar terhadap peningkatan kualitas kesehatan masyarakat. Puskesmas dan posyandu sebagai garda terdepan pelayanan kesehatan yang selama ini hanya dipandang/dimanfaatkan untuk pelayanan kuratif dan rehabilitatif harus dimanfaatkan masyarakat untuk kegiatan preventif yang diwujudkan dalam bentuk kegiatan imunisasi, keluarga berencana, pemeriksaan kehamilan, pemeriksaan tekanan darah, pemantauan tumbuh kembang balita, konsultasi gizi serta konsultasi kesehatan walaupun pada kenyataannya belum maksimal seperti yang diharapkan. ${ }^{22}$

Pendapat diatas sejalan dengan penelitian lainnya bahwa posyandu memiliki peran untuk memberikan informasi kesehatan bagi masyarakat dan sebagai pendorong masyarakat dalam menerapkan perilaku hidup bersih dan sehat, sehingga kader posyandu sebagai agent of change perlu juga untuk dibekali pengetahuan yang mumpuni dalam mendeteksi dini dan intervensi dini keadaan kesehatan balita termasuk anak berkebutuhan khusus seperti autis. ${ }^{23}$

Program kesehatan ibu dan anak merupakan program pengembangan kesehatan ibu/perempuan. Perempuan adalah tulang 
punggung sebuah negara terlebih lagi seorang ibu, sehingga apabila tulang punggung negara itu rapuh maka tidak akan mampu menopang keberlangsungan sebuah negara. Hal ini berarti kesehatan sebuah negara tergantung kepada seberapa sehatnya para ibu karena para ibu yang menyiapkan generasi di masa mendatang. Sejahteranya sebuah bangsa tergantung seberapa kuatnya kondisi perekonomian seorang ibu dikarenakan ibu yang mengatur dan menata ekonomi keluarga yang merupakan miniatur sebuah negara. ${ }^{22}$

Mengamati kondisi diatas maka peneliti berpendapat bahwa kondisi rendahnya pemanfaatan posyandu terutama pada bagi balita umur 12 - 59 bulan dipengaruhi oleh banyak faktor, dari sudut ibu balita sebagai sasaran/pengguna posyandu dan juga dari sudut pengurus dan pengelola posyandu dalam rangka menjamin kualitas pelayanan dan ketersediaan sarana prasarana posyandu yang secara tidak langsung akan mempengaruhi ketertarikan sasaran/pengguna untuk datang ke posyandu. Adapun salah satu pengurus dan pengelola posyandu yang memegang peranan penting adalah tokoh masyarakat, seperti lurah/kepala desa, ketua RT/RW, tenaga kesehatan, serta kader posyandu yang oleh beberapa responden dirasakan masing kurang.

Pembinaan dan pengawasan

pelaksanaan posyandu harus dilakukan secara berjenjang mulai dari pusat, provinsi, kabupaten/kota, kecamatan dan desa/kelurahan yang dilakukan dalam bentuk kegiatan sosialisasi, rapat koordinasi, konsultasi, workshop, lomba, penghargaan, maupun orientasi dan pelatihan. Sejalan dengan konsep awal pembentukan posyandu yang diharapkan mampu memberikan kemudahan dan mendekatkan pelayanan kesehatan dasar kepada masyarakat utamanya untuk mempercepat penurunan angka kematian ibu dan bayi, maka fungsi pembinaan pemerintah perlu dikoordinasikan dan diorganisasikan secara lebih jelas. ${ }^{10}$

Saat ini pemerintah telah mewajibkan seluruh posyandu menyusun dan mengaktifkan wadah Kelompok Kerja Operasional Posyandu atau yang sering disingkat Pokjanal Posyandu yang ditingkat desa/kelurahan dikenal dengan sebutan Pokja Posyandu. Pokjanal/Pokja
Posyandu tersebut meliputi 3 aspek manajemen dalam menjalankan fungsi pembinaannya, yaitu aspek program, aspek kelembagaan dan aspek personil atau sumber daya manusia pengelola posyandu. ${ }^{8}$

Provinsi Sumatera Selatan telah mengeluarkan Keputusan Gubernur Sumatera Selatan No. 223/KPTS/BPMPD/2016 tertanggal 29 Maret 2016 yang kemudian diperbarui Keputusan Gubernur Sumatera Selatan No. 496/KPTS/DPMD/2019 tertanggal 5 September 2019 mengenai Pembentukan Kelompok Kerja Operasional Pembinaan Pos Pelayanan Terpadu Tingkat Provinsi Sumatera Selatan. Kota Palembang menindaklanjuti dengan menyusun Keputusan Walikota Palembang No. 496.a/KPTS/Dinas PP, PA dan PM/2018 tertanggal 28 Nopember 2018 tentang Pembentukan Kelompok Kerja Operasional Pos Pelayanan Terpadu Kota Palembang. keberadaan SK tersebut hingga saat ini nyatanya belum optimal mendorong keterlibatan lintas sektor dan sektor kesehatan masih dianggap sebagai leading sector untuk pengelolaan posyandu.

Tugas kedepan yang perlu dilakukan adalah mengoptimalisasikan keberadaan posyandu menjadi pusat informasi terutama terkait informasi kesehatan masyarakat yang benar dan tepat sasaran dimana kader posyandu menjadi motor penggerak dan komunikator handal dengan masyarakat. Sebagai pendukung arah menempatkan posyandu sebagai pusat informasi maka sistem informasi posyandu mau tidak mau harus di prioritaskan untuk segera diaktifkan untuk menjadi sumber informasi yang lengkap, akurat, dan aktual dalam mendukung perencanaan pembinaan posyandu secara berjenjang. Kurangnya fasilitas posyandu seperti tempat kegiatan yang kurang layak karena seluruh posyandu yang ada di wilayah kerja puskesmas dilaksanakan di halaman rumah tokoh masyarakat atau salah satu kader, kurangnya meja untuk pelayanan sehingga ada beberapa kader posyandu dengan sukarela membawa meja dari rumahnya untuk digunakan pada hari buka posyandu serta alat pendukung lainnya yang menjadi salah satu penyebab belum optimalnya peran kader dilakukan. Luasnya wilayah kerja dan keterbatasan sumber daya manusia kesehatan 
di puskesmas juga mendorong belum optimalnya pembinaan puskesmas dan koordinasi dengan lintas sektor di luar kesehatan, seperti tokoh agama, lurah, camat dan sebagainya.

\section{Kesimpulan}

Faktor yang terbukti berhubungan dengan pemanfaatan posyandu di wilayah kerja puskesmas Tegal Binangun Kota Palembang yaitu umur ibu, jumlah balita, umur balita, status pekerjaan, pendidikan terakhir, tingkat pengetahuan dan sikap ibu. Probabilitas untuk rendah dalam pemanfaatan posyandu jika memiliki faktor-faktor risiko tersebut sebesar $84,1 \%$. Untuk meningkatkan pemanfaatan posyandu terutama pada kelompok balita umur 12-59 bulan antara lain mendorong dan meningkatkan kerjasama serta keterlibatan lintas sektor dalam pemenuhan kebutuhan dan peningkatan sarana prasarana posyandu, mendorong terealisasinya dengan segera sistem informasi posyandu berbasis website yang menyediakan data terkait posyandu secara real dan up to date yang tentunya sangat bermanfaatan untuk pelaksanaan pembinaan secara berjenjang. Selain itu juga, pemberian reward atau penghargaan kepada pelaksana terbaik posyandu di desa/kelurahan dan kader lestari menjadi salah satu motivasi bagi pelaksana posyandu di lapangan.

\section{Ucapan Terimakasih}

Terima kasih diucapkan kepada semua pihak yang telah membantu dalam penelitian ini khususnya kepada Dinas Kesehatan Kota Palembang dan Puskesmas Tegal Binangun Kota Palembang.

\section{Daftar Pustaka}

1. Kementerian Kesehatan RI. UU Kesehatan No. 36. Jakarta: Kementerian Kesehatan RI.

2. Kementerian PPN/Bappenas RI. 2015. Rancangan Teknokratik Rencana Pembangunan Jangka Menengah
Nasional 2020 - 2024. Jakarta: Kementerian PPN/Bappenas.

3. UNICEF. 2010. Improving Child Nutrition, The Achievable Imperative for Global Progress. Vol 18, no.8.

4. Holipah Asri Maharani dan Yoshiki Kuroda. 2018. Determinants of immunization status among 12- to 23month-old children in Indonesia (20082013): A multilevel analysis. BMC Public Health. 18 (1): 1-11.

5. Mukaromah, N.H dan Ratna Dwi Wulandari. 2015. Rekomendasi Peningkatan Pemanfaatan Posyandu oleh Ibu Balita berdasarkan Analisis Total Costumer Sacrifies. Jurnal Administrasi Kesehatan Indonesia. 13 (3): 1576-1580.

6. F. Anwar, Khomsan, D. Sukandar, H. Riyadi, dan E.S. Mudjajanto. 2010. High participation in the Posyandu nutrition program improved children nutritional status. Nutrition Research and Practice. 4 (3): 208.

7. Maisya I dan Putro G. 2011. Peran Kader dan Klian Adat dalam Upaya Meningkatkan Kemandirian Posyandu di Provinsi Bali”. Buletin Penelitian Sistem Kesehatan. 14(1): 40-48.

8. Kementerian Kesehatan RI. 2011. Pedoman Umum Pengelolaan Posyandu. Jakarta: Kementerian Kesehatan RI bersama Tim Pokjanal Posyandu Tingkat Pusat.

9. Kementerian Dalam Negeri RI. 2018. Peraturan Menteri dalam Negeri Republik Indonesia Nomor 18 Tahun 2018 Tentang Lembaga Kemasyarakatan Desa Dan Lembaga Adat Desa. pp.1-11.

10. Kementerian Kesehatan RI. 2011. Panduan Penyelenggaraan Pemberian Makanan Tambahan Pemulihan bagi Balita Gizi Kurang. Jakarta: Kementerian Kesehatan RI. 
11. Reyes G.H, Perez-Cuevas R, Sandoval A, Castillo R, Santos IJ, Doubova SV. 2004. The Family as a Determinant of Stunting in Children Living in Conditions of Extreme Poverty: a Case Control Study. BMC Pediatrics. 4: 57.

12. Kementerian Kesehatan RI. 2012. Ayo Ke Posyandu Setiap Bulan. Jakarta: Kementerian Kesehatan RI.

13. Dinas Kesehatan Provinsi Sumatera Selatan. 2018. Profil Kesehatan Provinsi Sumatera Selatan Tahun 2018.

14. Dinas Kesehatan Kota Palembang. 2018. Profil Kesehatan Kota Palembang Tahun 2018.

15. Notoatmodjo S. 2007. Kesehatan Masyarakat Ilmu Dan Seni. Jakarta: Rineka Cipta.

16. Kasumayanti, Erma dan INB. 2016. Faktor-faktor yang Menyebabkan Rendahnya Peran Ibu Balita ke Posyandu Desa Sungai Datar Wilayah Kerja Puskesmas Sungai Keranji Tahun 2016. Jurnal Doppler Universitas Pahlawan Tuanku Tambusai. 1 (2).

17. Lemeshow, S. dan S.K. Lwanga. 1991. Sample Size Determination in Health Studies A Practical Manual. Geneva: WHO.

18. Notoatmodjo S. 2003. Prinsip-Prinsip Dasar Ilmu Kesehatan.Jakarta: Rineka Cipta.

19. Aswadi, Sukrifikriyanti Syahrir dan Andi, S.A. 2018. Perilaku Ibu Terhadap Pemanfaatan Posyandu Balita di Wilayah Kerja Puskesmas Tarakan Kecamatan Wajo Kota Makassar. AlSihah Public Health Science Journal. 10: 12-25.

20. Kementerian Kesehatan RI. 2012. Kurikulum Dan Modul Pelatihan Kader Posyandu. Jakarta: Kementerian Kesehatan RI.
21. Sagala Husna Khotimatul. 2018. FaktorFaktor yang Mempengaruhi Kunjungan Ibu Balita Dalam Pemanfaatan Posyandu di Desa Sei Rotan Kecamatan Percut Sei Tuan Wilayah Kerja Puskesmas Bandar Khalipa Tahun 2017. Medan: Universitas Sumatera Utara.

22. Saefudin, Encang, Edwin Rizal dan Agus Rusman. 2017. Peran posyandu sebagai Pusat Informasi Kesehatan Ibu dan Anak. Record and Library Journal. 3 (2): 201-208.

23. Khoirunisa, Esdaniar, Ravik Karsidi dan Munawir Yusuf. 2019. The Role of Posyandu as Primary Health Care Services in Implementing Early Detection and Intervention for Autistic Children in Indonesia. International Journal of Multicultural and Multireligius Understanding. 6 (1): 101. 